\title{
MODEL PEMBELAJARAN MITIGASI BENCANA DALAM ILMU PENGETAHUAN SOSIAL DI SEKOLAH MENENGAH PERTAMA*)
}

\author{
Oleh: Enok Maryani**)
}

\begin{abstract}
Abstrak
Dinamika alam sangat memberikan dampak bagi kehidupan manusia, baik bersifat menguntungkan maupun merugikan. Sifat merugikan inilah yang kemudian dikenal dengan sebutan bencana. Untuk meminimalkan resiko atau kerugian bagi manusia, perlu pengetahuan, pemahaman, kesiapsiagaan keterampilan untuk mencegah, menditeksi dan mengantisipasi secara lebih dini tentang berbagai macam bencana atau lebih dikenal dengan istilah mitigasi bencana. Mitigasi meliputi aktivitas dan tindakan-tindakan perlindungan yang dapat diawali dari persiapan sebelum bencana itu berlangsung, menilai bahaya bencana, penanggulangan bencana, berupa penyelamatan, rehabilitasi dan relokasi. Pengetahuan, pemahaman dan keterampilan berprilaku dalam mencegah, menditeksi, mengansipasi bencana secara efektif dapat ditransformasikan, disosialisasikan melalui pendidikan IPS yang secara khusus membahas mengenai isu-isu masalah sosial.

Penelitian ini didesain untuk mengembangkan model mitigasi bencana dalam pembelajaran IPS SMP. Hasil kegiatan penelitian yang diharapkan adalah: (1) peta kompetensi dasar IPS yang mengandung mitigasi bencana, (2) deskripsi analisis kebutuhan penyusunan model mitigasi bencana dalam pembelajaran IPS, dan (3) seperangkat model mitigasi bencana dalam pembelajaran IPS. Metode yang digunakan adalah research and development (penelitian dan pengembangan). Untuk mengetahui kebutuhan akan pembelajaran bencana dilakukan survai di daerah yang rawan bencana yaitu Pangandaran (gempa dan tsunami), Sukabumi (gempa dan tsunami), Dayeuhkolot (Banjir), Lembang (longsor dan gunungapi), Cirebon (angin topan). Sampel terdiri dari 10 orang kepala sekolah, 10 dewan sekolah, 40 orang guru dan 81 orang siswa. Data diolah secara kuantitatif, untuk kemudian diinterpretasi sesuai dengan tujuan penelitian.

Model pembelajaran terpadu merupakan model implementasi kurikulum IPS yang dianjurkan untuk diaplikasikan di SMP khususnya untuk mengajarkan tema mitigasi bencana. Adapun metode pembelajaran yang paling tepat diterapkan adalah melalui metode Cooperative learning dan problem solving, disamping metode lainnya seperti diskusi, simulasi dan demonstrasi. Media pembelajaran yang dianggap efektif adalah film, gambar dan peta, sedangkan evaluasi pembelajaran dapat dipadukan antara test, portofolio dan performance. Selain itu, model pembelajaran mitigasi bencana dalam pelatihan, penataran guru dan refreshing guru terhadap materi IPS kebencanaan perlu diberikan sebelum disosialisasikan pada peserta didik.
\end{abstract}

Kata kunci: model pembelajaran, mitigasi bencana, Ilmu Pengetahuan Sosial. 
*) Hasil penelitian Hibah Bersaing yang didanai Dit P2M Ditjen Dikti

**) Prof. DR. Enok Maryani, MS., adalah dosen Jurusan Pendidikan Geografi FPIPS UPI

\section{Pendahuluan}

Alam dan manusia senantiasa mengalami dinamika, dinamika tersebut diperlukan untuk menemukan keseimbangan. Dinamika alam ada yang sangat menguntungkan bagi kehidupan manusia dan ada beberapa diantaranya yang dapat menimbulkan bencana bagi manusia. Beberapa dinamika alam, khususnya yang menimbulkan bencana bagi manusia dapat di diditeksi dan diantisipasi, seperti letusan gunung, angin topan, banjir, dan gempa. Adapula dinamika alam yang sulit diditeksi seperti gempa bumi. Untuk meminimalkan resiko atau kerugian bagi manusia, perlu pengetahuan, pemahaman, kesiapsiagaan keterampilan untuk mencegah, menditeksi dan mengantisipasi secara lebih dini tentang berbagai macam bencana khususnya di tempat-tempat yang memang rawan terhadap bencana alam tersebut.

Dalam tujuan pendidikan tersebut, tercerminkan adanya kualitas sumberdaya manusia yang terintegrasi antara kualitas akhlak, sikap, pengetahuan dan prilaku yang kreatif dan antisipatif. Pendidikan merupakan seperangkat sistem, yang mana di dalamnya mengandung sejumlah bahan ajar, guru, peserta didik, metode, media, prasarana dan sarana yang mendukung serta kebijakan pengambil keputusan di dunia pendididkan (stackholders) baik dalam skala mikro (kepala sekolah), maupun makro (menteri pendidikan). Menurut Alvin Toffler (1995) dalam mengembangkan dunia pendidikan harus mengacu kepada kebutuhan anak didik di masa yang akan datang dengan sebutan "super-industrial education system". Berkaitan dengan hal tersebut menut Tilaar (2000) diperlukan pokokpokok paradigma baru dalam pendidikan nasional, salah satunya diarahkan untuk mengembangkan tingkah laku yang menjawab tantangan internal dan global. Keduanya menuntut adanya human capital yang membawa keunggulan dalam sebuah persaingan atau kompetisi, atau tantangan. Karena itulah pendidikan dikembangkan dengan berbasis kompetensi.

Pendidikan merupakan upaya untuk mempersiapkan peserta didik untuk memiliki kemampuan intelektual, emosional, spiritual, dan sosial yang bermutu tinggi. Kompetensi yang dikembangkan adalah keterampilan dan keahlian bertahan hidup dalam perubahan, pertentangan, ketidakmenentuan, ketidakpastian, dan kerumitan-kerumitan dalam kehidupan. Kompetensi dasar ini merupakan standar yang ditetapkan secara nasional, namun dalam pelaksanaannya untuk mencapai kompetensi dasar itu disesuaikan dengan daerah dan sekolah masing-masing. Standar nasional mempunyai misi untuk menjadikan pendidikan unggul dan merata bagi semua. Standar nasional berisi kerangka tentang apa yang harus diketahui, dilakukan dan dimahirkan oleh siswa pada setiap tingkatan. Kemahiran tersebut dikenal dengan kecakapan hidup (life skill). Kecakapan hidup dalam hal ini bukan hanya keterampilan standar yang mengacu kepada orientasi kerja, namun lebih menekankan kepada menggali potensi siswa yang dapat dikembangkan untuk hidup 
lebih survive meliputi kecakapan: mengenai diri (self awarness), berpikir rasional (thinking skill), sosial (social skill), akademik (academic skill), dan vokasional (vocasional skill). Standar ini juga disertai dengan standar pembentukan akhlak mulia yang mengutamakan pembentukan sistem nilai untuk mewujudkan manusia Indonesia yang berkepribadian dan beretos kerja, serta berpartisipasi aktif, demokratis, dan berwawasan kebangsaan dalam kehidupan bermasyarakat, berbangsa, dan bernegara.

Ilmu Pengetahuan Sosial merupakan salah satu mata ajar di dunia pendidikan. Pengetahuan Sosial adalah bahan kajian yang terpadu yang merupakan penyederhanaan, adapasi, seleksi dan modifikasi dari konsep-konsep dan keterampilan disiplin ilmu sejarah, geografi, sosiologi, antropologi dan ekonomi yang diorganisasikan secara ilmiah dan psikologis untuk tujuan pembelajaran. Dijelaskan dalam National Council for the Social Studies, 1991 "The social studies are concerned with human relationship. Their content is derived principally from the scholarly disciplines of economic, geography, history, political science, and sociology and includes elements from other social sciences". Dalam rangka reorganisasi pendidikan menengah oleh sebuah komisi, yaitu Commission on the Reorganization of Secondary Education, tahun 1916, mendefinisikan IPS sebagai "the social studies are understood to be those whose subject matter related directly to the organization and development of human society, and to man as a member of social group".

Bencana telah menjadi isu pembangunan, karena hasil pembangunan yang telah dirintis puluhan bahkan ratusan tahun dapat musnah atau rusak seketika dengan adanya bencana, perekonomian masyarakat dan negara pun banyak mengalami kemuduran, banyak prasarana dan sarana ekonomi, sosial dan budaya yang rusak. Masyarakat yang terkena bencana seringkali harus menata ulang kehidupannya dari awal, mereka harus pindah ke tempat lain, dan mulai penghidupan di tempat baru.

Mitigasi (mitigate) berati tindakan-tindakan untuk mengurangi bahaya supaya kerugian dapat diperkecil. Mitigasi meliputi aktivitas dan tindakantindakan perlindungan yang dapat diawali dari persiapan sebelum bencana itu berlangsung, menilai bahaya bencana, penanggulangan bencana, berupa penyelamatan, rehabilitasi dan relokasi. Menurut Keputusan Menteri Dalam Negeri RI No. 131 Tahun 2003, mitigasi atau penjinakan adalah upaya dan kegiatan yang dilakukan untuk mengurangi dan memperkecil akibat-akibat yang ditimbulkan oleh bencana, yang meliputi kesiapsiagaan, kewaspadaan dan berbagai kemampuan untuk mengatasinya.

\section{Permusan Masalah}

Indonesia merupakan negara yang rawan akan bencana, Pengetahuan, pemahaman dan keterampilan berprilaku dalam mencegah, menditeksi, mengansipasi bencana secara efektif dapat ditransformasikan, disosialisasikan melalui pendidikan IPS yang secara khusus membahas mengenai isu-isu masalah 
sosial. Berdasarkan kondisi tersebut di atas, maka penelitian ini difokuskan pada masalah :

a. Sejauhmana kurikulum dan mata ajar IPS bermuatan mitigasi bencana ?

b. Bagaimanakah gambaran mitigasi bencana yang secara faktual dan implisit telah dilakukan di sekolah?

c. Sejauhmana keefektifan model pembelajaran yang telah dilakukan oleh para guru dalam meningkatkan pemahaman dan keterampilan tentang mitigasi bencana?

d. Model pembelajaran mitigasi yang bagaimanakah yang perlu dikembangkan di SLTP Jawa Barat?

Tujuan penelitian ini adalah untuk :

a. Mengidentifikasi mata ajar IPS yang bermuatan mitigasi bencana.

b. Menganalisis keefektifan proses pembelajaran yang bermuatan mitigasi bencana.

c. Mengevaluasi keefektifan model pembelajaran yang telah dilakukan oleh para guru dalam meningkatkan pemahaman dan keterampilan mengenai mitigasi bencana

d. Mengembangkan model pembelajaran mitigasi bencana

\section{Tinjauan Pustaka}

\section{a. Peran dan Hakikat Pendidikan}

Pendidikan merupakan proses multidimensional, tidak hanya berhubungan dengan pentransferan pengetahuan dan keterampilan, tapi juga memaparkan, menanamkan dan memberikan keteladanan dalam hal sikap, nilai, moralitas, ucapan, perbuatan dan gaya hidup. Patton (1997) mengungkapkan bahwa "according psychologists agree that IQ contributes only $20 \%$ of tehe factor that determine auccess, a full $80 \%$ comes from other factors, including emotional intelegence", selanjutnya dikatakan EQ meliputi self awareness, mood management, self motivation, impulse control and people skills. Semua tu mencerminkan bahwa dunia pendidikan tidaklah cukup hanya membuat peserta didik menjadi cerdas saja, kemampuan yang holitik dan terintegrasi sangat penting dalam mengantar peserta didik mampu bersaing secara global. Hal ini menuntut dan mencerminkan pula bahwa proses pendidikan tidak hanya berlangsung di dalam kelas tetapi juga di luar kelas, tidak hanya dilakukan oleh guru di sekolah tapi juga oleh orangtua, masyarakat dan elit-elit politik. Pendidikan mencerminkan adanya proses interaksi antara peserta didik dengan lingkungan sosial budaya dan dengan lingkungan alam. Perpaduan antara belajar secara langsung (learning by doing) dengan memberikan keteladanan menjadi bagian yang sangat penting untuk memberikan kepercayaan terhadap teori dan kenyataan.

Pendidikan pada hakikatnya adalah sebagai suatu proses bagi manusia dalam mengenali diri dengan segenap potensi yang dimilikinya serta memahami realitas yang dihadapinya (Suyanto, 2006). Undang-Undang No. 20 Tahun 2003 Pasal 1 menjelaskan bahwa Pendidikan adalah usaha sadar dan terencana untuk mewujudkan suasana belajar dan proses pembelajaran agar peserta didik secara 
aktif mengembangkan potensi dirinya untuk memiliki kekuatan spiritual keagamaan, pengendalian diri, kepribadian, kecerdasan, akhlak mulia, serta keterampilan yang diperlukan dirinya, masyarakat, bangsa dan negara. Selanjutnya dalam Pasal 3 tentang dasar, fungsi dan tujuan Pendidikan nasional berfungsi mengembangkan kemampuan dan membentuk watak serta peradaban bangsa yang bermartabat dalam rangka mencerdaskan kehidupan bangsa, bertujuan untuk berkembangnya potensi peserta didik agar menjadi manusia yang beriman dan bertakwa kepada Tuhan Yang Maha Esa, berakhlak mulia, sehat, berilmu, cakap, kreatif, mandiri, dan menjadi warga negara yang demokratis serta bertanggung jawab.

\section{b. Hakikat dan Tujuan Pembelajaran IPS}

Pengetahuan Sosial adalah bahan kajian yang terpadu yang merupakan penyederhanaan, adaptasi, seleksi dan modifikasi dari konsep-konsep dan keterampilan disiplin ilmu sejarah, geografi, sosiologi, antropologi dan ekonomi yang diorganisasikan secara ilmiah dan psikologis untuk tujuan pembelajaran. Dijelaskan dalam (National Council for the Social Studies, 1991 "The social studies are concerned with human relationship. Their content is derived principally from the scholarly disciplines of economic, geography, history, political science, and sociology and includes elements from other social sciences". Dalam rangka reorganisasi pendidikan menangah oleh sebuah komisi, yaitu Commission on the reorganization of secondary education, tahun 1916, mendefinisikan IPS sebagai "the social studies are understood to be those whose subject matter related directly to the organization and development of human society, and to man as a member of social group". adalah

Ilmu Pengetahuan Sosial (Socal Studies) menurut NCSS, tahun 1992,

Social studies is the integrated study of the social sciences and humanities to promote civic competence. Within the social program, social studies provide coordinated, systematic study drawing upon such disciplines as anthropology, archeology, economic, economic, geography, history, law, philosophy, political science, psychology, religion and sociology, as well as appropriate content from the humanities, mathematic and natural sciences. The primary purpose of social studies is to help young people develop to ability to make informed and reasoned decisions for the public good as citizens of a culturally diverse, democratic, society in an interdependent world (Stahl dan Hartoonian, 2003).

Sementara itu karakteristik IPS adalah (1) involves a search for pattern in our liver; (2) involves both the content and processes of learning (3) requires information processing; (4) requires problem solving and decision making; (5) involves the development and analysis of one's own value and application of these values in social action.

IPS merupakan bagian dari dari kurikulum sekolah yang tanggungjawab utamanya adalah membantu peserta didik dalam mengembangkan pengetahuan, 
keterampilan, sikap, nilai yang diperlukan untuk berpartisipasi dalam kehidupan masyarakat baik di tingkat lokal, nasional maupun global. Hal ini sejalan dengan tujuan kurikulum IPS tahun 2004 yaitu mengkaji seperangkat fakta, peristiwa konsep, dan generalisasi yang berkaitan dengan prilaku manusia untuk membangun dirinya, masyarakatnya, bangsanya dan lingkungannya berdasarkan pada pengalaman masa lalu yang dapat dimaknai untuk masa kini dan diantisipasi untuk masa yang akan datang.

IPS sebegai suatu pelajaran diberikan di jenjang persekolahan yaitu SD, SMP dan SMA. di SD dan SMP diberikan secara terintegrasi, namun dalam Standar Isi masih tampak adanya materi tang terpisah-pisah (separated), di SMA sebagai ilmu sosial yang terpisah-pisah, walaupun payungnya dalam kurikulum tetap IPS.

Bart Shermis (1978) menjelaskan bahwa penggunaan social studies sebagai integrasi dari ilmu-ilmu sosial dan humanities untuk kepentingan pendidikan kewarganegaraan, sedangkan Dufty (1970) menggunakan dan mengartikan IPS sebagai "the process of learning to live with other people". Dari uraian tersebut tampak bahwa IPS bertujuan untuk melatih peserta didik agar berfikir sistematis, kritis, bersikap dan bertindak sehingga adaptable terhadap kehidupan masyarakat. Dengan demikian guru dituntut untuk melatih peserta didik untuk menemukan suatu isu-isu/masalah atau consensus yang ada dalam kehidupan masyarakat (Suyanto, 2005). Ilmu Pengetahuan Sosial (IPS) merupakan integrasi dari berbagai cabang ilmu-ilmu sosial seperti: sosiologi, sejarah, geografi, ekonomi, politik, hukum, dan budaya. Ilmu Pengetahuan Sosial dirumuskan atas dasar realitas dan fenomena sosial yang mewujudkan satu pendekatan interdisipliner dari aspek dan cabang-cabang ilmu-ilmu sosial (sosiologi, sejarah, geografi, ekonomi, politik, hukum, dan budaya). IPS atau studi sosial itu merupakan bagian dari kurikulum sekolah yang diturunkan dari isi materi cabang-cabang ilmu-ilmu sosial: sosiologi, sejarah, geografi, ekonomi, politik, antropologi, filsafat, dan psikologi sosial (Model Pembelajaran terpadu IPS, Pusat Kurikulum, 2006).

Di SMP, IPS diajarkan untuk memahami dan mengembangkan pengetahuan, nilai, sikap dan keterampilan sosial dan kewarganegaraan fakta, peristiwa, konsep, dan generalisasi. Sehingga ia mampu merefleksikan dalam kehidupan masyarakat, bangsa, dan negara Indonesia. Adapun tujuannya adalah

a. Mengembangkan pengetahuan dasar kesosiologian, kegeografian, keekonomian, kesejarahan, dan kewarganegaraan.

b. Mengembangkan kemampuan berpikir, inquiri, pemecahan masalah,dan keterampilan sosial.

c. Membangun komitmen dan kesadaran terhadap nilai-nilai kemanusiaan.

d. Meningkatkan kemampuan berkompetisi dan bekerja sama dalam masyarakat yang majemuk, baik dalam skala nasional maupun skala internasional.

\section{c. Model Pembelajaran IPS}


Pembelajaran merupakan sesuatu yang dilakukan peserta didik, bukan dibuat oleh peserta didik "learning is something student do, not something that is done to student" (Johnson and Johnson, 1994). Dalam melakukan sesuatu itu peserta didik senantiasa dibantu dan diarahkan oleh pendidik sehingga apa yang diperbuatnya menjadi terarah dan sesuai dengan tujuan yang hendak dicapai.Seperti yang dikatakan oleh Sudjana (2000) pembelajaran merupakan upaya pendidik untuk membantu peserta didik melakukan kegiatan belajar. Kegiatan pembelajaran itu sendiri merupakan pencapaian seperangkat nilai, sikap, persepsi, prilaku dan sejumlah pengetahuan yang bermakna bagi kehidupan peserta didik. Pendidik selalu mengarahkan tujuan pembelajaran agar dapat dicapai secara efektif dan efisien. Pihak-pihak yang terlibat dalam pembelajaran antara lain kurikulum, guru, peserta didik, media pembelajaran dan situasi pembelajaran itu sendiri. Semuanya saling berinteraksi dan berinterdepensi, sehingga dapat menentukan kualitas pencapaian tujuan tersebut.

Piaget berpendapat bahwa interaksi pembelajaran berlangsung secara terus menerus yang dilakukan oleh individu dengan lingkungannya, sedangkan lingkungan itu sendiri senantiasa mengalami perubahan. Dengan perubahan lingkungan tersebut, berarti fungsi pembelajaran senantiasa berkembang. Hamalik (2001) mendefinisikan pembelajaran sebagai suatu kombinasi yang tersusun secara sistematis antara manusia, material, fasilitas, perlengkapan dan prosedur, guna mencapai tujuan. Manusia yang terlibat dalam di sekolah anatara lain guru, kepala sekolah, peserta didik dan tata usaha, material berupa buku, papan tulis, foto, dan ausio visual. Prosedur meliputi jadual dan metode penyampaian informasi termasuk model pembelajaran, praktik, ujian, dan sebagainya.

Model adalah suatu pencerminan, penggambaran sistem yang nyata atau abstraksi dari dunia nyata yang disederhanakan sehingga hanya parameterparameter penting saja yang muncul, dapat mendeskripsikan hubungan antar parameter baik secara kualitatif maupun kuantitatif. Menurut Horton (1972) sebuah model harus mencerminkan atau mengabstraksikan sebuah objek, peristiwa, situasi atau sistem. Secara lebih luas, sebuah model adalah sesuatu yang mengungkap dan menjelaskan tentang hubungan dari berbagai komponen, aksi, reaksi serta sebab akibat.

Menurut Hasan (1996) model pembelajaran harus memenuhi prinsip sebagai berikut (1) pembelajaraan harus semakin baik, jika upaya yang dilakukan guru makin kecil dan aktivitas belajar peserta didik makin besar; (2) semakin sedikit waktu yang diperlukan oleh guru dalam mengaktifkan peserta didik untuk belajar maka pembelajaran akan makin baik; (3) sesuai dengan cara pembelajaran yang dilakukan oleh peserta didik; (4) dapat dilaksanakan dengan baik oleh guru; (5) sebenarnya tidak ada satu pun metode yang sempurna yang paling sesuai dengan tujuan, jenis materi dan proses belajar yang ada.

Ibrahim (2000) menjelaskan ada 3 model pembelajaran yang dapat diterapkan dikelas yaitu :

1. Pembelajaran individual (individualistic learning) : peserta didik merasa yakin bahwa pencapaian tujuan belajar akan dengan baik tercpai bila 
dilakukan sendiri, tidak berinteraksi dengan peserta didik lain dan tidak tergantung pada baik buruknya pencapaian orang lain;

2. Pembelajaran kompetetif (competitive learning) terjadi bila seseorang peserta didik dapat mencapai suatu hasil yang baik maka peserta didik yang lain tidak dapat mendapatkan hasil yang baik (win-losss situation). Dengan demikian setiap usaha yang dilakukan oleh individu untuk mencapai tujuan merupakan saingan bagi individu lain.

3. Pembelajaran kooperatif (cooperative learning) terjadi jika peserta didik dapat mencapai tujuan mereka bila peserta didik lain yang bekerjasama dapat mencapai hasil tersebut. Tiap-tiap individu ikut andil dalam menyumbang pencapaian tujuan tersebut.

\section{Metode Penelitian}

\section{a. Desain Penelitian}

Penelitian ini didesain untuk mengembangkan model mitigasi bencana dalam pembelajaran IPS SMP. Hasil kegiatan penelitian yang diharapkan adalah: (1) peta kompetensi dasar IPS yang mengandung mitigasi bencana, (2) deskripsi analisis kebutuhan penyusunan model mitigasi bencana dalam pembelajaran IPS, dan (3) seperangkat model mitigasi bencana dalam pembelajaran IPS.

Untuk mencapai target tersebut, maka pelaksanaan kegiatan penelitian ini dilakukan dengan karakteristik sebagai berikut: (1) analisis dokumen kurikulum IPS SMP, mengkaji teori yang terkait, dan analisis dokumen lain yang terkait; (2) analisis kebutuhan (need assessment) berkaitan dengan penyusunan model mitigasi bencana; (3) penyusunan draft model mitigasi bencana dalam pembelajaran IPS yang sifatnya hipotetik dan siap untuk diujicobakan; (4) penyusunan instrumen untuk uji coba model dan bahan ajar; serta (6) uji coba dengan cara implementasi draft model di sekolah.

Produk yang dihasilkan pada tahap pertama di tahun pertama ini adalah:

1) Peta penyebaran kompetensi dasar mata pelajaran IPS yang bermuatan mitigasi bencana.

2) Deskripsi hasil analisis kebutuhan siswa, guru, dan kepala sekolah dalam kaitannya dengan pengembangan model mitigasi bencana.

3) Seperangkat model mitigasi bencana pada pembelajaran IPS SMP yang sifatnya hipotetik untuk diriviu dan diujicobakan.

Metode yang digunakan dalam penelitian ini adalah research and development (penelitian dan pengembangan). Oleh karena itu, penelitian ini dilakukan dengan cara dua tahap selama dua tahun. Untuk mengetahui kebutuhan akan pembelajaran bencana dilakukan survai di daerah yang rawan bencana yaitu Pangandaran (gempa dan tsunami), Sukabumi (gempa dan tsunami), Dayeuhkolot (Banjir), Lembang (longsor dan gunungapi), Cirebon (angin topan). Sampel terdiri dari 10 orang kepala sekolah, 10 dewan sekolah, 40 orang guru dan 81 orang siswa. 
Data diolah secara kuantitatif, untuk kemudian diinterpretasi sesuai dengan tujuan penelitian.

\section{Hasil Penelitian}

\section{a. Analisis Kurikulum IPS}

Berdasarkan analisis kurikulum IPS di jenjang SMP, ternyata sebagaian besar standar isi dan kompetensi dasar IPS dapat disisipkan muatan mitigasi bencana. Berdasarkan need assesment dari pihak kepala sekolah, komite sekolah, dan guru, muatan kurikulum mempunyai persentasi yang cukup besar (> $40 \%$ ) untuk disisipkan muatan mitigasi bencana, yaitu pelajaran yang bernuansa sejarah yaitu sebagai berikut.

Kelas VII Semester 2 :

5.1 Mendeskripsikan perkembangan masyarakat, kebudayaan dan pemerintahan pada masa Hindu-Budha, serta peninggalan-peninggalannya

5.2 Mendeskripsikan perkembangan masyarakat, kebudayaan, dan pemerintahan pada masa Islam di Indonesia, serta peninggalan-peninggalannya

5.3 Mendeskripsikan perkembangan masyarakat, kebudayaan dan pemerintahan pada masa Kolonial Eropa

Kelas VIII Semester 1 :

2.1 Menjelaskan proses perkembangan kolonialisme dan imperialisme Barat, serta pengaruh yang ditimbulkannya di berbagai daerah

2.2 Menguraikan proses terbentuknya kesadaran nasional, identitas Indonesia, dan perkembangan pergerakan kebangsaan Indonesia

Kelas IX Semester 1 :

1.1 Mengidentifikasi ciri-ciri negara berkembang dan negara maju

1.2 Mendeskripsikan Perang Dunia II (termasuk pendudukan Jepang) serta pengaruhnya terhadap keadaan sosial, ekonomi, dan politik di Indonesia

2.1 Mengidentifikasi usaha perjuangan mempertahankan kemerdekaan Indonesia

2.2 Mendeskripsikan peristiwa-peristiwa politik dan ekonomi Indonesia pasca pengakuan kedaulatan

Kelas IX Semester 2

6.1 Mendeskripsikan perjuangan bangsa Indonesia merebut Irian Barat

6.2 Mendeskripsikan peristiwa tragedi nasional Peristiwa Madiun/PKI, DI/TII, G 30 S/PKI dan konflik-konflik internal lainnya

7.1 Menjelaskan berakhirnya masa Orde Baru dan lahirnya Reformasi

7.2 Menguraikan perkembangan lembaga-lembaga internasional dan peran Indonesia dalam kerjasama internasional

7.3 Menguraikan perilaku masyarakat dalam perubahan sosial-budaya di era global

7.4 Mendeskripsikan kerjasama antarnegara di bidang ekonomi 
7.5 Mengidentifikasi dampak kerjasama antarnegara terhadap perekonomian Indonesia

Untuk materi yang bernuansa Ekonomi porsi yang cukup besar ( $40 \%$ ) sebagai berikut :

Kelas VII Semester 2 :

6.3 Mendeskripsikan peran badan usaha, termasuk koperasi, sebagai tempat berlangsungnya proses produksi dalam kaitannya dengan pelaku ekonomi

6.4 Mengungkapkan gagasan kreatif dalam tindakan ekonomi untuk mencapai kemandirian dan kesejahteraan

Kelas VIII Semester 2 :

7.1 Mendeskripsikan permasalahan angkatan kerja dan tenaga kerja sebagai sumber daya dalam kegiatan ekonomi, serta peranan pemerintah dalam upaya penanggulangannya

7.2 Mendeskripsikan pelaku-pelaku ekonomi dalam sistem perekonomian Indonesia

7.3 Mendeskripsikan fungsi pajak dalam perekonomian nasional

7.4 Mendeskripsikan permintaan dan penawaran serta terbentuknya harga pasar

Kelas IX Semester 1 :

4.1 Mendeskripsikan uang dan lembaga keuangan

4.2 Mendeskripsikan perdagangan internasional dan dampaknya terhadap perekonomian Indonesia

Materi yang bernuansa Geografi semuanya sangat sesuai untuk disisipi materi mitigasi bencana, bahkan melalui geografi sebab, akibat dan indikator bencana serta mitigasi dapat diberikan secara menyeluruh baik bencana alam berupa gunung api, gempa, tsunami, angin topan atau badai, longsor dan bencana alam lainnya, maupun bencana sosial.

Materi yang bernuansa sosiologi merupakan materi yang relevan untuk menggali nilai-nilai sosial dan etika bermasyarakat, baik secara lokal, regional, nasional bahkan internasional. Materi bencana sosial yang bernuansa interaksi sosial dan penyakit sosial pun dapat disisipkan melalui sosiologi dan antropologi.

Materi yang bernuansa ekonomi dapat menjelaskan dampak bencana terhadap kehidupan masyarakat khususnya dalam pemenuhan kebutuhan, dan alokasi sumberdaya, serta dampaknya terhadap laju pembangunan suatu negara.

Berdasarkan analisis kebutuhan tersebut maka model IPS terpadu dengan tema mitigasi dapat digambarkan seperti berikut ini.

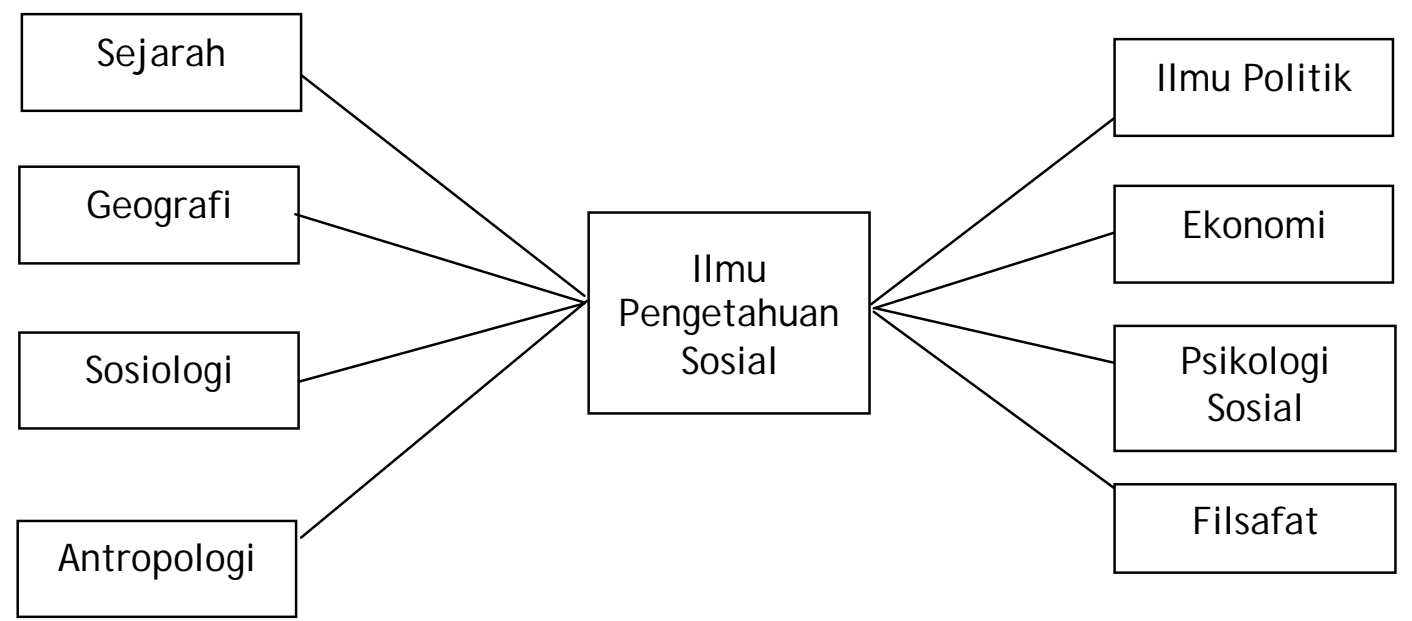




\section{Gambar 1. Keterpaduan Cabang Ilmu Pengetahuan Sosial}

- Keragaman bentuk bumi, proses pembentukan dan dampaknya terhadap kehidupan

- Kondisi geografis Indonesia dan dunia, melalui peta, atlas dan globe

- Gejala atmosfer, hidrosfer, litosfer, dan dampakanya bagi kehidupan

- Pola kegiatan ekonomi berdasarkan kondisi fisik
- Manusia sebagai makhluk sosial dan ekonomi yang bermoral

- Tindakan, kegiatan ekonomi, proses produksi serta distribusi

- Distribusi sumberdaya

- Akibat bencana di suatu wilayah secara ekonomi dan usaha mengantisipasi serta menanggulanginya

\section{Segi Geografi}

Segi Ekonomi

BENCANA

- Kehidupan sosial : proses dan bentuk interaksi sosial

- Penyakit sosial

- Bencana Sosial dan mitigasniynya
- Perkembangan masyarakat dan kebudayaannya

- Peristiwa bencana alam dan sosial dari Indonesia dari waktu ke waktu

Segi Sosiologis

Segi Sejarah

\section{Gambar 2. Model Integrasi IPS Berdasarkan masalah Mitigasi Bencana}

\section{b. Profile Pembelajaran IPS}

Jumlah rombongan belajar desa sampel menunjukkan variasi yang cukup tinggi, untuk sekolah yang ada di kabupaten Bandung jumlah rombongan belajar berkisar antara 9 sampai 11 robel, jumlah tersebut konsisten untuk setiap kelas. Di Daerah Sukabumi, Cirebon dan Pangandaran, rombongan belajar berkisar antara 4 sampai 8. Banyaknya rombongan belajar tersebut, membuat beban mengajar guru menjadi semakin besar. Jumlah rata-rata perkelas adalah 45 orang, dengan ratio guru dan siswa berkisar antara 1: 25. Jumlah guru IPS, di tiap sekolah berkisar 
antara 3 sampai 6 orang. Sekolah di luar Kabupaten Bandung umumnya hanya memiliki 3 orang guru IPS saja, pembagian tugas umumnya per kelas.

Sebagian besar guru IPS sudah mencapai S1, yang artinya sudah memenuhi standar minimal pendidikan guru, dan $41 \%$ di antaranya masih D3, dengan jurusan yang relevan yaitu IPS dengan bidang studi atau jurusan geografi, sejarah, dan ekonomi. Media pembelajaraan IPS yang paling banyak di miliki oleh sekolah adalah peta, yaitu Peta Indonesia yang sifatnya umum, globe, dan atlas, selain itu buku paket menjadi sumber pembelajaran yang sangat penting, dan hanya sebagian kecil saja yang sudah memiliki infokus (LCD).

Informasi mengenai keberadaan bencana di lingkungan sekolah ternyata sebagian besar menyatakan ada, yaitu berupa gempa bumi, banjir, kekeringan, badai dan di sekitar pantai (Pangandaran dan Sukabumi) ada tsunami serta ombak pasang yang besar. Kondisi ini mendorong pembelajaran mengenai bencana dan mitigasi perlu diberikan untuk menmberikan pemahaman, pengetahuan dan kesiapan bertindak kalau bencana itu datang dan membahayakan masyarakat.

Informasi mengenai kebencaanaan termasuk mitigasinya, ternyata belum pernah mereka terima, umumnya mereka mengetahui tentang bencana dari berbagai mas media seperti Koran dan TV, sehingga pemahamannya pun sangat terbatas. Kurikulum lokal yang mentransformasikan pengetahuan bencana pun belum pernah mereka kembangkan. Hal ini wajar mengingat adanya keterbatasan pengetahuan yang mereka miliki. Pemahaman mereka tentang bencana hanya sedikit sehingga tidak mempunyai pemahaman yang cukup untuk ditransformasikan ke peserta didik. Pendapat mengenai mata pelajaran yang paling relevan untuk memberikan bekal mengenai kebencanaan dan usaha mengantisipasinya, maka IPS adalah pilihan yang dominan, hanya sebagian kecil saja yang menyatakan pelajaran IPA. Sehingga berdasarkan analisis kurikulum dan analisis kebutuhan mengenai informasi tentang kebencanaan maka pelajaran IPS memang paling sesuai, khususnya berkenaan dengan materi kegeografian, karena melalui geografianlah materi kebumian secara fisikal dan dampaknya terhadap kehidupan manusia diajarkan.

Pengetahuan tentang kebencanaan para guru, kepala sekolah dan dewan sekolah ternyata umumnya tidak dipahami dengan baik, mencapai $70 \%$ dari responden menyatakan sedikit dan tidak paham tentang peristiwa kebencanaan. Hal ini menunjukkan pengetahuan kebencanaan tidak hanya perlu diberikan pada peserta didik tapi juga stackholder dalam hal ini kepala sekolah, dewan sekolah dan guru sebagai pengajar. Kebutuhan akan pembekalan materi atau refreshing materi kebencanaan perlu diberikan baik melalui penataran, seminar atau pelatihan terlebih dahulu diberikan pada guru, kepala sekolah dan dewan sekolah sebelum kepada peserta didik, agar informasi diberikan lebih akurat dan dapat dipertanggung jawabkan.

Ketidakpahaman mengenai mitigasi bencana nampak pula dari jawaban responden mengenai pertanyaan tentang metode yang dianggap efektif dalam pembelajaran mitigasi bencana. Sebagian besar responden $(70 \%)$ menyatakan ceramah dan tanya jawab, hanya sebagian kecil yang menyatakan simulasi. 
Media yang dianggap efektif dalam pembelajaran kebencanaan termasuk mitigasinya adalah melalui gambar dan penayangan film. Hal ini menunjukkan visualisasi dari macam-macam bencana, termasuk mitigasinya sangat penting untuk mengkongkritnya sesuatu yang bersifat abstrak, terutama bagi peserta didik, yang mana bencana masih belum menjadi peristiwa yang kongkrit operasional. Bagi kepala sekolah, dewan sekolah ataupun guru yang berlatar pendidikan non geografi mungkin masih bersifat abstrak, dan informasi hanya diterima dari berbagai media masa yang sifatnya pasif.

Pendapat mengenai sejauhmana kurikulum yang sekarang diberlakukan dapat memberikan pemahaman tentang bencana dan mitigasinya, ternyata sebagian besar $(50 \%)$ responden menyatakan cukup memadai, $40 \%$ menyatakan tidak memadai dan hanya sebagian kecil $(10 \%)$ yang menyatakan tidak memadai. Hal ini menunjukkan perlu adanya pengayaan kurikulum baik melalui muatan lokal atau pun KTSP untuk lebih dikembangkan materi tentang materi kebencanaan secara implisit dikemukakan dalam kurikulum, untuk kemudian dikembangkan sesuai dengan kerawanan daerah terhadap bencana. Pembelajaran mitigasi bencana dapat pula diberikan secara lintas kurikulum, bersama-sama dengan pelajaran lain baik yang serumpun atau pun tidak, yang pasti harus ada alokasi waktu secara khusus untuk membahas kebencanaan khususnya tentang mitigasinya.

\section{c. Respon Kepala Sekolah dan Komite Sekolah Terhadap Materi dan Pemahaman Pembelajaraan Kebencanaan}

Materi muatan lokal mengenai kebencanaan merupakan materi yang sangat penting, mengingat banyak terjadinya bencana di Indonesia. Pengetahuan kita terhadap pemahaman bencana di lingkungan sekitar merupakan awal dari pengenalan materi kebencanaan dan bagaimana siswa dapat mengetahui cara penanggulangan bencana. Untuk mengetahui daerah-daerah yang potensial terjadinya bencana di Indonesia umumnya (75\%) sangat penting untuk dipelajari, jenis bencana yang potensial terjadi di lingkungan sekolah dan tempat tinggal (70\%) merupakan contoh kongkrit dari pengenalan muatan lokal pembelajaraan mengenai materi kebencanaan.

Pemahaman tentang pencegahan bencana $(80 \%)$ dirasakan sangat penting hal ini bahwa bagaiamana kita dapat mengantisipasi terjadinya bencana, namun pemahaman mengenai kebencanaan ini perlu diimbangi dengan macam-macam materi tentang kebencanaan yakni: peringatan dini terhadap bencana, bagaimana cara penanggulangan bencana tersebut yang merupakan segmentasi muatan lokal (90\%) yang mesti diajarkan kepada setiap peserta didik, yang terdiri dari beberapa aspek muatan lokal yang mesti dikenalkan kepada peserta didik yaitu: tindakan untuk menghadapi bencana (70\%) sangat penting, tindakan untuk mengatasi bencana $(75 \%)$ sangat penting pula, dan bagaimana tindakan dalam menghadapi pasca bencana ( 55\%) sangat penting untuk dikenalkan kepada peserta didik.

Model dari pembelajaran IPS terpadu ini terdiri dari kurikulum, guru, metode, media, dan evaluasi dari materi muatan lokal mengenai materi kebencanaan. Kurikulum mengenai kebencanaan ini merupakan bagian dari IPS 
terpadu yang secara tematis dapat dipelajari, sehingga dari IPS terpadu ini kita dapat mengetahui bahwa materi kebencanaan merupakan ilmu yang memiliki kesinambungan untuk dikembangkan materi tentang materi kebencanaan secara implisit dikemukakan dalam kurikulum IPS di SMP. Dalam memperoleh materi kebencanaan guru perlu mengikuti pelatihan dan refreshing agar dalam menyampaikan materi mengenai kebencanaan guru dapat memilih metode pembelajaran yang cocok untuk diterapkan pada setiap bahasan. Sebagai rekomendasi guru dapat memilih metode ceramah dan Tanya jawab, diskusi, simulasi ataupun demonstrasi terhadap materi mengenai kebencanaan.

Dalam memilih metode simulasi ataupun demonstrasi siswa dapat diajak untuk mengenalkan bagaimana cara penanggulangan bencana sehingga siswa dapat melakukan tindakan terhadap bencana yang terjadi disekitar lingkungan mereka. Sedangkan media yang dapat digunakan didalam materi kebencanaan ini adalah peta, gambar, dan film sebagai ilustrasi terjadinya bencana. Bentuk evaluasi yang dapat siswa ikuti dapat berbentuk portofolio ataupun dengan performance siswa. Dari pembelajaraan mengenai kebencanaan siswa dapat diupayakan mengenal karakteristik mengenai kebencanaan, dapat mengetahui daerah rawan bencana. Hasil yang diperoleh siswa dalam memahami dan mengetahui materi kebencanaan ini adalah pengetahuan, sikap, dan prilaku, informasi yang akurat serta penanggulangan bencana dan tindakan untuk menghadapi bencana dan pasca bencana.

INPUT
PROSES
OUTPUT 


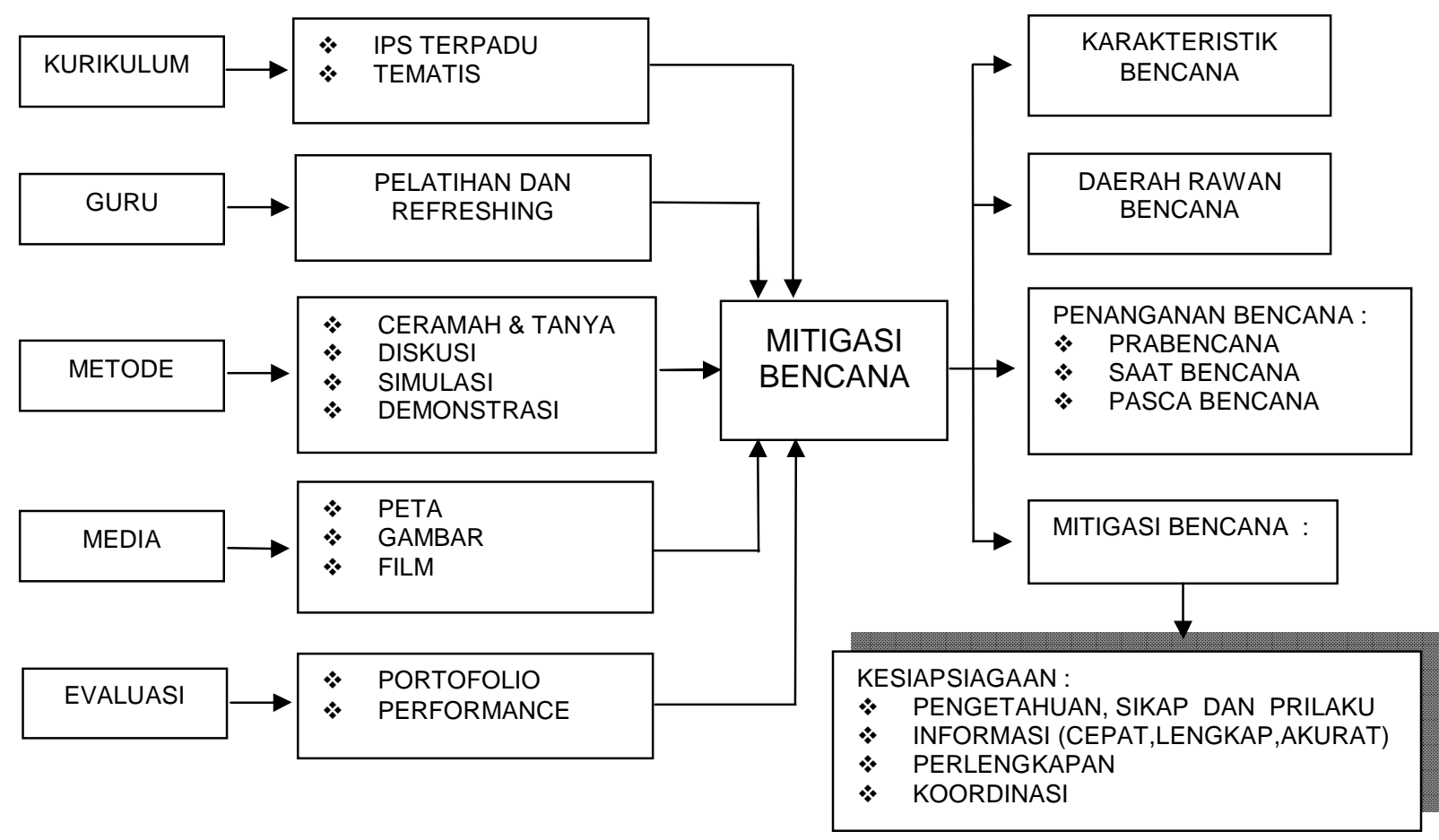

\section{Penutup}

\section{a. Kesimpulan}

Model pembelajaran terpadu merupakan model implementasi kurikulum IPS yang dianjurkan untuk diaplikasikan di SMP khususnya di IPS untuk mengajarkan tema mitigasi bencana. Model pembelajaran terpadu pada hakikatnya merupakan suatu pendekatan pembelajaran yang memungkinkan peserta didik baik secara individual maupun kelompok aktif mencari, menggali, dan menemukan konsep serta prinsip secara holistik dan otentik. Perolehan keutuhan belajar, pengetahuan, serta kebulatan pandangan tentang kehidupan dan dunia nyata hanya dapat direfleksikan melalui pembelajaran terpadu. Kelemahannya seringkali sulit untuk mengintegrasikan/mentemakan mata pelajaran, pelajaran jadi parsial, dan seringkali guru menjadi kekurangan waktu. Tim teaching sebenarnya merupakan cara yang terbaik untuk pembelajaran IPS, walaupun ada juga beberapa kendala diantaranya (1) guru harus lebih banyak waktu untuk berdisikusi dalam tim guna menyiapkan pembelajaran (2) tidak terikat bahan salah bahan ajar/sumber bahan ajar beragam (3) menyamakan persepsi antarguru IPS yang berbeda latarbelakang ilmu dan etos kerja.

Cooperative learning dan problem solving adalah metode yang paling tepat dalam pembelajaran IPS, melalui diskusi, simulasi dan demonstrasi. Media pembelajaran yang dianggap efektif adalah film, gambar dan peta, sedangkan evaluasi pembelajaran dapat dipadukan antara test, portofolio dan performance.

Kepala sekolah, dewan sekolah, guru dan murid sebagian besar menyatakan bahwa pembelajaran mitigasi bencana sangat penting dan penting untuk diberikan. 
Karakteristik bencana, berbagai indikator terjadinya bencana, daerah rawan terhadap bencana di Indonesia serta mitigasi bencana merupakan materi yang sangat penting untuk diajarkan. Selain itu pelatihan, penataran guru dan refreshing guru terhadap materi IPS kebencanaan perlu diberikan sebelum disosialisasikan pada peserta didik.

\section{b. Saran}

1) Pemahaman IPS secara terpadu dan tematis perlu disosialisasikan dengan baik termasuk peningkatan pengetahuan dan keterampilan para guru mengenai kemitigasian bencana, melalui pelatihan atau refreshing materi ajar IPS..

2) Mengingat guru memiliki andil yang besar dalam mengembangkan kurikulum kebencanaan, maka seyogyanya pembelajaran IPS dilakukan melalui team teaching, sehingga dapat memudahkan guru dalam memberikan materi termasuk pemilihan metode dan media pembelajaraan. Sharing pengetahuan antarguru bidang studi dalam membahas mitigasi bencana sangat diperlukan sehingga memiliki persepsi yang sama dalam memecahkan masalah bencana dan mitigasinya.

3) Lintas kurikulum pada setiap akhir semester perlu dilakukan untuk memelihara keterampilan mitigasi secara terpadu.

4) Perlu ada buku panduan khusus mengenai materi kebencanaan dan mitigasinya baik bagi guru maupun peserta didik.

\section{Daftar Pustaka}

Amstrong, David G, 1980, Social Studies in Secondary Education, MacMillan Pub. Co. New York.

Banks, James, A and Cherry, A., Mc Gee Banks, 1999, Teaching Strategies for The Social Studies, Longman, New York.

Bureasu of Education in Bulletin Volume No. 43/1916, Report of The Committee on Social Studies, Commission on the Reorganization of Secondary

Education. The US Bureau of Education Washington, DC.

Coburn, AW, R.J.S. Spence dan A. Pomonis, 1994, Mitigasi Bencana, Cambridge Architectural Research Limited, The Oast House, Malting Lane, Cambridge, United Kingdom http://www.undmtp.org/Indonesian/Disaster_mitigation/Mitigasi

Direktorat Vulkanologi dan Mitigasi Bencana, Departemen Energi dan Sumberdaya Mineral, Gempa Bumi dan Tsunami. Bandung.

Fielding, 1974, Geography as Social Science, London : Haarper International Edition

Gustavo Wilches, 1995, Bencana dan Lingkungan, Program Pelatihan manajemen Bencana, UNDP.

Hamid Hasan, 2005, Implementasi Pendidikan IPS dalam menghadapi Tantangan Global, Bandung, Universitas Pendidikan Indonesia.

Hamid Hassan, 1995, Pendidikan Ilmu Sosial, Jakarta : Dekdikbud DIKTI- Proyek Peningkatan Tenaga Akademik. 
Maryani, Enok, Geografi, bahan ajar untuk SMP, Jakarta : Erlangga.

Michalis, 1980, Social Studies for Children, New Jersey : Prentice Hall.

NCSS, 1994, Curriculum Standard for Social Studies : Expectation of Excellece Washington.

National Commission for Social Studies. In Search of a Scope and Sequence for Social Studies, Social Education, April 1984.

Reed, Shelia, 1995, Pengantar Tentang Bahaya, Program Pelatihan Manajemen Bencana.UNDP.

Sarwedi Oemarmadi, "Pendidikan dan Mitigasi Bencana Alam; Pelajaran Berharga dari Aceh", Homepage Pendidikan Network, Tanggal 2 Januari 2005. Suwarma Al Muctar, 2005, Strategi Pembelajaran IPS, Pascasarjana UPI.

Undang-Undang Republik Indonesia Nomer 20 Tahun 2003 Tentang Pendidikan Nasional

UNDP, 1992, Tinjauan Umum Manajemen Bencana, Program Pelatihan Manajemen Bencana.

Zarrillo, James, J.,2000, Teaching Elementary Social Studies, Printice Hall, Columbus $\mathrm{OH}$. 